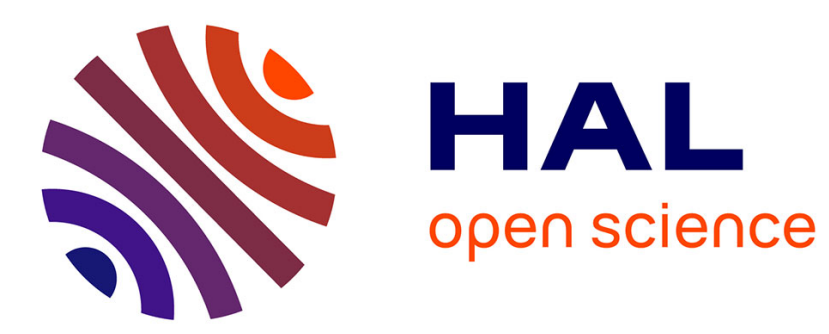

\title{
Incretin-based therapy for the treatment of bone fragility in diabetes mellitus
}

\author{
Guillaume Mabilleau, Benoit Gobron, Béatrice Bouvard, Daniel Chappard
}

\section{To cite this version:}

Guillaume Mabilleau, Benoit Gobron, Béatrice Bouvard, Daniel Chappard. Incretin-based therapy for the treatment of bone fragility in diabetes mellitus. Peptides, 2018, 100, pp.108-113. 10.1016/j.peptides.2017.12.008 . hal-02869266

\section{HAL Id: hal-02869266 \\ https://univ-angers.hal.science/hal-02869266}

Submitted on 15 Jun 2020

HAL is a multi-disciplinary open access archive for the deposit and dissemination of scientific research documents, whether they are published or not. The documents may come from teaching and research institutions in France or abroad, or from public or private research centers.
L'archive ouverte pluridisciplinaire HAL, est destinée au dépôt et à la diffusion de documents scientifiques de niveau recherche, publiés ou non, émanant des établissements d'enseignement et de recherche français ou étrangers, des laboratoires publics ou privés. 


\title{
Incretin-based therapy for the treatment of bone fragility in diabetes mellitus
}

\author{
Guillaume Mabilleau $^{\mathrm{a}, \mathrm{b}, \mathrm{c}, * \text {, Benoît Gobron }}{ }^{\mathrm{a}, \mathrm{d}}$, Béatrice Bouvard ${ }^{\mathrm{a}, \mathrm{d}}$, Daniel Chappard ${ }^{\mathrm{a}, \mathrm{b}, \mathrm{c}}$ \\ a GEROM-LHEA UPRES EA4658, University of Angers, Institut de Biologie en Santé, Angers, France \\ ${ }^{\mathrm{b}}$ SCIAM, University of Angers, Institut de Biologie en Santé, Angers, France \\ ${ }^{\mathrm{c}}$ Bone Pathology Unit, Angers University Hospital, Angers, France \\ d Rheumatology Department, Angers University Hospital, Angers, France
}

\section{A R T ICLE IN F O}

\section{Keywords:}

Bone

GIP

GLP-1

Incretins

Digestive hormones

\begin{abstract}
A B S T R A C T
Bone fractures are common comorbidities of type 2 diabetes mellitus (T2DM). Bone fracture incidence seems to develop due to increased risk of falls, poor bone quality and/or anti-diabetic medications. Previously, a relation between gut hormones and bone has been suspected. Most recent evidences suggest indeed that two gut hormones, namely glucose-dependent insulinotropic polypeptide (GIP) and glucagon-like peptide-1 (GLP-1), may control bone remodeling and quality. The GIP receptor is expressed in bone cells and knockout of either GIP or its receptor induces severe bone quality alterations. Similar alterations are also encountered in GLP-1 receptor knock-out animals associated with abnormal osteoclast resorption. Some GLP-1 receptor agonist (GLP-1RA) have been approved for the treatment of type 2 diabetes mellitus and although clinical trials may not have been designed to investigate bone fracture, first results suggest that GLP-1RA may not exacerbate abnormal bone quality observed in T2DM. The recent design of double and triple gut hormone agonists may also represent a suitable alternative for restoring compromised bone quality observed in T2DM. However, although most of these new molecules demonstrated weight loss action, little is known on their bone safety. The present review summarizes the most recent findings on peptide-based incretin therapy and bone physiology.
\end{abstract}

\section{Introduction}

Diabetes mellitus is progressing worldwide. A report from the International Diabetes Federation estimated that 415 million individuals were suffering of diabetes mellitus worldwide in 2015. Projections for 2040 estimate a burden at approximately 642 million individuals [1]. Diabetes mellitus is characterized by a decrease in production of insulin (type 1 diabetes mellitus - T1DM) or by resistance to insulin (type 2 diabetes mellitus - T2DM) that ultimately result in higher circulating glucose concentrations.

Among all complications associated with diabetes mellitus, bone fractures represent a significant health issue for patients with T1DM or T2DM. Etiology of bone fracture in diabetes mellitus has recently been the topic of several reviews and as such will not be discussed further in the present paper [2-4]. However, it seems that in diabetes, fractures occur as a consequence of increased risk of falls, low bone quality and bone turnover, and may be exacerbated by anti-diabetic medications such as thiazolidinediones or SGLT2 inhibitors [5]. Management of fracture prevention relies on improving glycemic control and reducing falls. However, it is important to bear in mind that no diabetes-specific guidelines for fracture prevention exist although it is admitted that those appropriate for older adults in general delineate strategies that are also applicable to those with diabetes. However, these guidelines have been established for patients with low bone mineral density and may not reflect what happens in T2DM, where bone mineral density may be normal or slightly higher. Concerns regarding the use of anti-resorptive strategies (bisphosphonate, raloxifene, denosumab), that may further reduce the already existing low bone turnover, have also been expressed [6] and may not be the most suitable intervention especially with regards to the higher occurrence of atypical femoral fracture in postmenopausal women with diabetes [7]. Anabolic agents such as teriparatide may represent a more suitable approach in diabetes, but although positive data have been reported in pre-clinical animal studies, human data are scarce [8].

The gastrointestinal (GI) tract is one of the largest endocrine organs with more than 12 specialized endocrine cells [9]. Among the plethora of bioactive peptides that the GI tract secretes, a class of peptides called incretins has emerged as important modulators of energy metabolism. The term "incretin" was initially proposed by Creutzfeld in 1979

\footnotetext{
* Corresponding author at: GEROM-LHEA UPRES EA 4658, Institut de Biologie en Santé, Université d'Angers, 4 Rue Larrey, 49933 Angers Cedex 09 , France.

Email address: guillaume.mabilleau@univ-angers.fr (G. Mabilleau)
} 
and represents hormones that are secreted from the intestine in response to glucose and stimulate insulin release in a glucose-dependent manner [10]. Although several hormones with insulinotropic action are secreted by the gut, glucose-dependent insulinotropic polypeptide (GIP) and glucagon-like peptide-1 (GLP-1) are the only two physiological incretins identified so far [11]. Based on the glucose-lowering properties of GLP-1, several GLP-1 receptor agonists have been designed and approved for the treatment of T2DM. Recently, based on knockout preclinical animal models, potential beneficial effects of both GIP and GLP-1 have been highlighted and may represent a suitable therapeutical option in the treatment of diabetes-induced bone fragility. The goal of the present review is to summarize the beneficial bone effects of GIP, GLP-1 and GLP-1 receptor agonist.

\section{Glucose-dependent insulinotropic polypeptide (GIP)}

GIP is produced and secreted mostly by intestinal K-cells, located primarily in proximal regions of the small intestine. The K-cell is highly polarized with the GIP-containing secretory granules concentrated at the basal pole of the cell and released through the basolateral membrane upon stimulus $[12,13]$. Based on the morphological features, GIP secretion from K-cells is regulated by neural stimuli, hormones and intraluminal contents [14]. K-cells are found in close association with the capillary network running through the lamina propria allowing GIP to enter into the blood stream rapidly after secretion. Furthermore, intraluminal contents do not only affect GIP secretion but also GIP expression. Indeed, glucose and lipids are potent stimulators of GIP gene transcription $[15,16]$.

Recent evidences suggested that the GIP/GIP receptor (GIPr) pathway is an important regulator of bone physiology. The first argument is represented by the expression at the mRNA and protein levels of the GIPr in osteoblasts and osteoclasts [17-20]. Interestingly, the expression of the GIPr is augmented in murine osteoblast by glucose treatment in the presence of BMP-2 [21]. In osteoblast cultures, GIP administration results in increases in intracellular calcium and cAMP that lead to augmentations in type I collagen expression, alkaline phosphatase and lysyl oxidase activities, and higher enzymatic collagen cross-linking [18,22]. In osteoclast cultures, GIP is capable of reducing the extent of osteoclast formation and resorption by fully mature human and murine osteoclasts through direct inhibitions of calcium oscillation and NFATc1 nuclear translocation after RANKL stimulation $[20,23,24]$.

The phenotype of GIP- and GIPr-deficient animals has been previously reported. GIP-GFP-KI mice, generated by the insertion of an EGFP-poly(A)-loxp-Neo-loxp cassette into exon 3 of wild type Gip gene, are defective in releasing GIP [25]. These mice present with a lower trabecular bone mass associated with higher osteoclast surface [26]. Interestingly, conflicting results have been reported in mice lacking a functional GIPr. Indeed, two animal models have been generated: the first one lacks exons 4 and 5 of the mouse Gipr gene and seems to exhibit lower trabecular bone mass [24,27]. The second model lacks exons 1-6 and exhibits a high trabecular bone mass and a low cortical bone mass associated with alterations of bone quality $[28,29]$. However, as the lack of a functional GIPr leads to increased GLP-1 sensitivity [30-32], we wondered whether the observed bone phenotype observed in GIPr KO mice resulted from the direct lack of GIPr or by a compensatory mechanism induced by elevated sensitivity to GLP-1. To answer this question, the bone phenotype of double incretin receptor knockout (DIRKO) animals, lacking both the GIPr and GLP-1r, was investigated [33]. DIRKO animals also exhibit profound reductions in bone mass, as well as, alterations of trabecular and cortical microarchitectures and tissue material properties demonstrating the important role of incretins in bone physiology.
Physiologically, circulating levels of intact bioactive GIP are extremely low due to rapid degradation in the mucosa of the small intestine by hematopoietic- and endothelial cell DPP4 directly after its secretion [34]. As such, several GIP analogues have been developed to be enzymatically resistant to degradation [35]. Preclinical data on the use of GIP mimetic in animal models are scarce nevertheless, administration of N-Acetyl-GIP (N-AcGIP) ameliorated tissue material properties when administered for 28 days in healthy rodents [36]. Furthermore, in streptozotocin-injected mice, developing a classical picture of type 1 diabetes, with a compromised bone mass and microarchitecture as well as tissue material properties, the administration of [D-Ala $\left.{ }^{2}\right]$ GIP for 21 days resulted in bone turnover almost similar to non-diabetic animals, and reduction in matrix collagen destruction [37]. These results are very interesting as insulin release was unchanged in [D-Ala $\left.{ }^{2}\right]$-treated as compared with saline-treated mice, suggesting that these beneficial effects of GIP mimetic are independent of insulin secretion.

In healthy humans, although initially GIP had been shown ineffective in reducing bone resorption [38], recent evidences suggested that exogenous administration of GIP was effective in reducing circulating markers of bone resorption [39]. However, whether these results reflect direct actions of GIP on osteoclast-mediated resorption or indirect actions of other GIP-targeted tissues remain to be determined in the future. Furthermore, the link between GIP/GIPr pathway and bone mass/ strength is definitely established and represented by low mineral bone density at the femoral neck and total hip, as well as higher incidence of non-vertebral fractures, in a cohort of perimenopausal women with a single-nucleotide polymorphism (rs1800437), that results in decreased GIPr activity [40,41].

\section{Glucagon-like peptide-1 (GLP-1)}

GLP-1 is produced and secreted by enteroendocrine L-cells after processing of the proglucagon gene [11]. Despite two forms of GLP-1 might be produced in the intestine, GLP- $1_{7-36 \mathrm{NH} 2}$ is the major form [42]. As K-cells, L-cells are also open type endocrine cells highly polarized with secretory granules at their basolateral pole. GLP-1 secretion from L-cells is regulated by intraluminal contents, neural stimuli and hormones [43]. L-cells are found in close association with the capillary network running through the lamina propria. GLP-1 has also been suspected to act via the autonomous nerve system and vagal afference on specific hypothalamic and brainstem nuclei to exert its action [44]. GLP-1 is rapidly degraded in the mucosa of the small intestine by endothelial cell DPP4.

Presence of the known GLP-1r in bone cells was controversial until recently. Indeed, this confusion was due to the use of poorly characterized cell lines [17], selection of wrong primer pairs [45], or the use of non-selective anti-GLP-1r antibodies [21] that were not very specific of the mouse Glp1r gene. Recent evidences by Pereira et al. seem to suggest the presence of the known GLP-1r in skeletal tissues [46]. However, other studies failed to demonstrate the presence of GLP-1r in MC3T3-E1 [47] or primary murine osteoblasts or osteoclasts [28] and this discrepancy needs to be investigated in the future. Nevertheless, previous studies in other tissues such as liver and skeletal muscle revealed the presence of a second GLP-1 receptor different from the known GLP-1r in function and/or structure. Indeed, this second GLP-1 receptor does not activate the cAMP pathway as GLP-1r does but rather the production of inositolphosphoglycan as a second messenger $[48,49]$. Nuche-Berenguer et al. revealed the presence of this second GLP-1 receptor in the MC3T3-E1 murine osteoblastic cell line [47]. However, as recent evidences pointed out that GLP-1 could bind to the glucagon receptor in certain circumstances [50], it would be compulsory to ascertain whether this second GLP-1r corresponds to a modulation of ligand specificity at the glucagon receptor. 
The bone phenotype of GLP-1r KO revealed an interesting bone phenotype. These animals exhibit reductions in trabecular bone volume and cortical thickness, altered bone strength and compromised bone quality $[51,52]$. At the cellular level, the number of osteoclasts and eroded surfaces were increased with no apparent effects on osteoblast activity [52]. Taken together these results suggested a control of bone resorption (osteoclast differentiation and/or action) by the GLP-1r despite no direct action of GLP-1 in controlling osteoclast formation and resorption in osteoclast cultures [52]. However, in humans, administration of exogenous GLP-1 does not result into lower CTx levels [38]. Recently, evidences have been provided that the GIPr was expressed by C-cells of the thyroid gland in rodents, but not in non-human primate or humans, and responsible for calcitonin secretion [53]. Taken together, these observations highlight that a functional GLP-1r is not only required for the control of bone resorption but also for the preservation of an optimal bone matrix quality.

Several GLP-1 receptor agonists resistant to DPP4 degradation have been designed and recently approved for the treatment of T2DM [54]. Among them, exenatide (also known as exendin-4) and liraglutide represent the leading molecules. GLP-1r is expressed by mesenchymal stem cells present in the bone marrow. Activation of GLP-1r by GLP-1 maintains proliferation of MSC and blocks their differentiation into adipocytes by modulating key adipocyte gene [55]. Furthermore, exenatide has been shown to protect MSC from apoptosis and endoplasmic reticulum stress [56]. GLP-1 and its analogues also modulate osteoblast proliferation and differentiation by activating different intracellular pathways, namely PI3K/Akt, ERK 1/2, cAMP/PKA, AMPK/mTOR and c-fos [57-61]. On the other hand, few data are available on the effect of GLP-1 or its analogue in the differentiation and activation of osteoclast cells in vitro. Several pre-clinical and proof-of-concept studies have been undertaken in animal models with skeletal fragility (T1DM, T2DM and OVX-induced osteoporosis). Mechanistically, administration of GLP- $1_{7-36 \mathrm{NH} 2}$ or exenatide, a GLP-1r agonist, results in a rapid augmentation of osteocalcin gene expression and, reductions in sclerostin expression and in the balance RANKL/OPG $[45,62,63]$. In type- 1 diabetes mellitus, administration of liraglutide for 21 days contributed to significant improvement in bone strength at the tissue levels and reduction in collagen degradation in the bone matrix [37]. However, no improvements in neither trabecular nor cortical bone microarchitecture were observed. Nevertheless, these mild ameliorations occurred in the absence of insulin secretion. Due to the marketing of GLP-1 mimetic for type 2 diabetes, the efficacy of GLP-1 analogues has been performed in type 2 diabetic rodent models. In this condition, the administration of liraglutide ameliorated trabecular and cortical bone microarchitectures [64]. It is, however, worth noting that the administration of liraglutide has been performed at a dose regiment of $0.4 \mathrm{mg} / \mathrm{kg} /$ day as compared with the $0.02 \mathrm{mg} / \mathrm{kg} /$ day used in human clinical trials $[65,66]$. The effects of GLP-1 mimetic have also been conducted in osteoporotic rodent models. Indeed, 16 weeks administration of exenatide (dose regimen of $10 \mu \mathrm{g} / \mathrm{kg}$ /day similar to the dose used in humans [67]) in OVX rats, is capable of improving trabecular bone mass and microarchitecture at the femur and lumbar vertebra, bone strength and revert hyper-resorption observed after ovariectomy [68]. Furthermore, these results were confirmed by Pereira et al. [46]. It is also noteworthy that at this dose regimen, exenatide was incapable of reversing the observed deterioration of cortical microarchitecture. Pereira et al., also reported positive effects of liraglutide $(0.3 \mathrm{mg} / \mathrm{kg} /$ day $)$ in improving trabecular but not cortical microarchitecture [46]. However, administration of liraglutide at a dose of $1.8 \mathrm{mg} / \mathrm{kg} /$ day for 8 weeks, significantly improved trabecular and cortical microarchitecture [69]. This dose regimen is 90 times more elevated than the dose given to humans. Moreover, recently, evidences have been provided that undercarboxylated osteocalcin was capable of inducing GLP-1 release from the L-cells and as such, this complementary mechanism reinforced the role of osteocalcin in energy expenditure [70,71].

Although now several GLP-1 receptor agonists have been approved for the treatment of T2DM, data regarding the safety and efficacy of such approach on bone strength and fracture risk is scarce. In 2014, we conducted the first meta-analysis of randomized clinical trials of GLP-1 receptor agonist based on the little amount of data available at that time [72]. Our study included 2918 patients treated with a GLP-1RA and 1337 treated with a comparator. This meta-analysis reported that the risk of developing a bone fracture was not elevated (OR 0.75 [95\% CI 0.28-2.02], but also not reduced as one could have expected from pre-clinical data, in T2DM patients. A year later, Su et al., reassessed this risk by performing a meta-analysis including 5040 patients treated with a GLP1RA and 3410 treated with a comparator [73]. The overall assessment confirmed the above findings (OR 1.05 [95\% CI 0.59-1.87]. However, as the number of patients was greater, a molecule-based analysis was conducted and highlighted a possible reduction of the risk of fracture with liraglutide (OR 0.38 [95\% CI 0.17-0.87] and a higher risk with exenatide (OR 2.09 [95\% CI 1.03-4.21]. Retrospective case-control studies based on the Clinical Practice Research Datalink and the Danish National Health Service registry demonstrated a neutral role of GLP-1RA on fracture risk [74,75]. Recently, Paschou et al. summarize the most recent evidences on the skeletal effects of GLP-1RA on fracture risk and reached the conclusion that although a controlled trials designed to assess the fracture risk under GLP-1RA treatment with bone fracture as the primary outcome is still lacking, GLP-1RA therapy seems neutral in term of bone metabolism and fracture risk [76].

\section{Double and triple analogue molecules}

Recently, double and triple agonists of gut hormone receptors have been designed and successfully synthesized (Table 1 ). The rationale behind using these double and triple molecules arises from the additive effects brought by co-administration of single receptor agonists. The majority of double and triple agonists exhibit action at the GLP-1r, glucagon receptor (GCGr), GIPr and cholecystokinin B receptor (CCK $\mathrm{BR}$ ). All these molecules showed positive effects on plasma glucose and weight loss in rodent models of T2DM [77-86] but little information has been provided in term of bone strength apart from [D-Ala ${ }^{2}$ ] GIP-Oxm. This data would be very interesting in order to ascertain the safety of such therapeutical intervention as weight loss is often consider as a negative factor for bone strength, especially in overweight and obese patients $[87,88]$. NNC0090-2746 has also recently been successfully used in a 12 week, randomized, placebo-controlled, double blind phase 2a trial of patients with T2DM inadequately controlled with metformin [89]. Apparently, no fracture occurs in both arms (NNC0090-2746- and placebo-treated) but the relatively low amount of patients included in this phase 2a trial (37 patients treated with $1.8 \mathrm{mg}$ NNC0090-2746 and 36 patients treated with placebo) might not have been enough to highlight bone safety of this therapeutical approach. Currently, the only available data are those provided by Mansur et al., who investigated bone strength in the $\mathrm{db} / \mathrm{db}$ mouse model after administration of [D-Ala $\left.{ }^{2}\right]$ GIP-Oxm. It seems that [D-Ala $\left.{ }^{2}\right]$ GIP-Oxm significantly improved bone strength at the organ and tissue level [90]. This improved bone strength was mediated through ameliorations of trabecular bone microarchitecture and collagen maturity and lower collagen glycation.

\section{Conclusions}

A clear link between incretins and bone physiology has been demonstrated and incretins appear as potent modulators of bone mass but also of bone quality and ultimately bone strength. However, the major challenge to face in this field in the future will be to ascertain by 
Table 1

Summary of double and triple agonists exploiting the incretin pathway.

\begin{tabular}{|c|c|c|c|}
\hline Name & Peptide sequence & Agonism at & Reference \\
\hline Aib2 C24 lactam 40k & HXQGTFTSDYSKYLDEQAAKEFIC $^{\text {aWLMNT }}{ }_{-\mathrm{NH} 2}$ & GLP1r, GCGr & [78] \\
\hline DualAG & HSQGTFTSDYSKYLDSRRAQDFVQWLMNTKRNRNNIA-Cholesterol & GLP1r, GCGr & {$[85]$} \\
\hline ZP 2495 & HSQGTFTSDYSKYLDRARADDFVAWLKST $_{-{ }_{-N H}}$ & GLP1r, GCGr & {$[90]$} \\
\hline$\left[\mathrm{D}-\mathrm{Ala}^{2}\right] \mathrm{GLP} 1 / \mathrm{GcG}$ & Y[D-Ala]EGTFISDYSKYLDSRRAQDFIAWLVKGR ${ }_{-\mathrm{NH} 2}$ & GLP1r, GCGr & {$[82]$} \\
\hline ZP 3022 & HGEGTFTSDLSKQMEEEAVRLFIEWLKN-8Ado-8Ado-YGWLDF $_{-\mathrm{NH} 2}$ & GLP1r, CCK-BR & {$[81]$} \\
\hline Twinincretin (Compound 18) & YXEGTFTSDYSIYLDKQAAXEFVNWLLAGGPSSGAPPPSK $_{-\mathrm{NH} 2}$ & GIPr, GLP1r & [79] \\
\hline NNC0090-2746 (RG7697 or compound 19) & 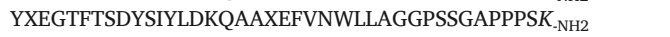 & GIPr, GLP1r & [79] \\
\hline Compound 21 & YXEGTFTSDYSIYLDKQAAXEFVC*WLLAGGPSSGAPPPSK $_{-\mathrm{NH} 2}$ & GIPr, GLP1r & [79] \\
\hline [D-Ala ${ }^{2}$ GIP-Oxm & Y[D-Ala]EGTFISDYSKYLDSRRAQDFVQWLMNTKRNRNNIA & GIPr, GLP1r, GCGr & [76] \\
\hline YAG-Glucagon & Y[D-Ala]QGTFTSDYSIYLDSNVAQDFVQWLIGG & GIPr, GLP1r, GCGr & [77] \\
\hline Triagonist & HXQGTFTSDKSKYLDERAAQDFVQWLLDGGPSSGAPPPS $_{-\mathrm{NH} 2}$ & GIPr, GLP1r, GCGr & {$[80]$} \\
\hline (pGlu-Gln)-CCK-8/Exendin-4 & $\mathrm{H}(\mathrm{pE}) \mathrm{QDYMGWMDFZZHGEGTFTSDLSKQMEEEAVRLFIEWLKN}{ }_{-\mathrm{NH} 2}$ & GLP1r/CCK-BR & [84] \\
\hline GIP/Xenin & Y[D-Ala]EGTFISDYSIAMHPQQPWIL & GIPr, NT1R? & [83] \\
\hline
\end{tabular}

$\mathrm{X}$ is aminoisobutyric acid, $\mathrm{Z}$ is $\{2$-[2-aminoethoxy]ethoxy $\}$ acetic acid. Side chains of underlined amino acids are covalently coupled. Italic letters represent site of acylation.

a PEGylation.

which mechanisms incretins exert their control on skeletal physiology and to demonstrate the efficacy of incretin therapies in bone diseases with compromised bone strength. Furthermore, as the use of double and triple agonists seems promising, it will also be a prerequisite to ascertain their effects on bone strength more in detail.

\section{Conflict of interest}

None of the authors has a conflict of interest to declare.

\section{Authors' contribution}

GM, BG, BB and DC actively wrote the manuscript. All authors have approved the final version of this manuscript.

\section{Acknowledgement}

This work was supported by the SATT Ouest Valorisation (grant number DV-2541 to GM) and by an institutional grant from the University of Angers.

\section{References}

[1] I.D. Federation, IDF Diabetes Atlas, 2015

[2] F.S. Hough, D.D. Pierroz, C. Cooper, S.L. Ferrari, I.C. Bone, G. Diabetes Working, Mechanisms in endocrinology: mechanisms and evaluation of bone fragility in type 1 diabetes mellitus, Eur. J. Endocrinol. 174 (4) (2016) R127-38.

[3] N. Napoli, M. Chandran, D.D. Pierroz, B. Abrahamsen, A.V. Schwartz, S.L. Ferrari, I.O.F. Bone, G. Diabetes Working, Mechanisms of diabetes mellitus-induced bone fragility, Nat. Rev. Endocrinol. 13 (4) (2017) 208-219.

[4] D.E. Sellmeyer, R. Civitelli, L.C. Hofbauer, S. Khosla, B. Lecka-Czernik, A.V. Schwartz, Skeletal metabolism, fracture risk, and fracture outcomes in type 1 and type 2 diabetes, Diabetes 65 (7) (2016) 1757-1766.

[5] A.V. Schwartz, Diabetes, bone and glucose-lowering agents: clinical outcomes, Diabetologia 60 (7) (2017) 1170-1179.

[6] L.M. Coe, S.A. Tekalur, Y. Shu, M.J. Baumann, L.R. McCabe, Bisphosphonate treatment of type I diabetic mice prevents early bone loss but accentuates suppression of bone formation, J. Cell. Physiol. 230 (8) (2015) 1944-1953.

[7] L.Y. Park-Wyllie, M.M. Mamdani, D.N. Juurlink, G.A. Hawker, N. Gunraj, P.C. Austin, D.B. Whelan, P.J. Weiler, A. Laupacis, Bisphosphonate use and the risk of subtrochanteric or femoral shaft fractures in older women, JAMA 305 (8) (2011) 783-789.

[8] K.J. Motyl, L.K. McCauley, L.R. McCabe, Amelioration of type I diabetes-induced osteoporosis by parathyroid hormone is associated with improved osteoblast survival, J. Cell. Physiol. 227 (4) (2012) 1326-1334.

[9] J.B. Furness, L.R. Rivera, H.J. Cho, D.M. Bravo, B. Callaghan, The gut as a sensory organ, Nat. Rev. Gastroenterol. Hepatol. 10 (12) (2013) 729-740.

[10] W. Creutzfeldt, The incretin concept today, Diabetologia 16 (2) (1979) 75-85.

[11] D.J. Drucker, The biology of incretin hormones, Cell Metab. 3 (3) (2006) 153-165.

[12] A.M. Buchan, J.M. Polak, C. Capella, E. Solcia, A.G. Pearse, Electronimmunocytochemical evidence for the K cell localization of gastric inhibitory polypeptide (GIP) in man, Histochemistry 56 (1) (1978) 37-44.

[13] S. Sykes, L.M. Morgan, J. English, V. Marks, Evidence for preferential stimulation of gastric inhibitory polypeptide secretion in the rat by actively transported carbohydrates and their analogues, J. Endocrinol. 85 (2) (1980) 201-207.
[14] Y.M. Cho, T.J. Kieffer, K-cells and glucose-dependent insulinotropic polypeptide in health and disease, Vitam. Horm. 84 (2010) 111-150.

[15] Y. Higashimoto, E.C. Opara, R.A. Liddle, Dietary regulation of glucose-dependent insulinotropic peptide (GIP) gene expression in rat small intestine, Comp. Biochem. Physiol. Part C Pharmacol. Toxicol. Endocrinol. 110 (2) (1995) 207-214.

[16] C.C. Tseng, L.A. Jarboe, M.M. Wolfe, Regulation of glucose-dependent in sulinotropic peptide gene expression by a glucose meal, Am. J. Physiol. 266 (5 Pt 1) (1994) G887-91.

[17] E.L. Pacheco-Pantoja, L.R. Ranganath, J.A. Gallagher, P.J. Wilson, W.D. Fraser, Receptors and effects of gut hormones in three osteoblastic cell lines, BMC Physiol. 11 (2011) 12.

[18] R.J. Bollag, Q. Zhong, P. Phillips, L. Min, L. Zhong, R. Cameron, A.L. Mulloy, H. Rasmussen, F. Qin, K.H. Ding, C.M. Isales, Osteoblast-derived cells express functional glucose-dependent insulinotropic peptide receptors, Endocrinology 141 (3) (2000) 1228-1235.

[19] G. Mabilleau, C. Gaudin-Audrain, N. Irwin, P.R. Flatt, M.F. Basle, D. Chappard, Deficiency in glucose-dependent insulinotropic peptide receptor results in higher bone mass in male mice, Osteoporos. Int. 23 (Suppl. 2) (2012) S407-8.

[20] Q. Zhong, T. Itokawa, S. Sridhar, K.H. Ding, D. Xie, B. Kang, W.B. Bollag, R.J. Bollag, M. Hamrick, K. Insogna, C.M. Isales, Effects of glucose-dependent insulinotropic peptide on osteoclast function, Am. J. Physiol. Endocrinol. Metab. 292 (2) (2007) E543-8.

[21] E. Aoyama, I. Watari, K.A. Podyma-Inoue, M. Yanagishita, T. Ono, Expression of glucagon-like peptide-1 receptor and glucosedependent insulinotropic polypeptide receptor is regulated by the glucose concentration in mouse osteoblastic MC3T3-E1 cells, Int. J. Mol. Med. 34 (2) (2014) 475-482.

[22] A. Mieczkowska, B. Bouvard, D. Chappard, G. Mabilleau, Glucose-dependent insulinotropic polypeptide (GIP) directly affects collagen fibril diameter and collagen cross-linking in osteoblast cultures, Bone 74 (2015) 29-36.

[23] G. Mabilleau, R. Perrot, A. Mieczkowska, S. Boni, P.R. Flatt, N. Irwin, D. Chappard, Glucose-dependent insulinotropic polypeptide (GIP) dose-dependently reduces osteoclast differentiation and resorption, Bone 91 (2016) 102-112.

[24] K. Tsukiyama, Y. Yamada, C. Yamada, N. Harada, Y. Kawasaki, M. Ogura, K. Bessho, M. Li, N. Amizuka, M. Sato, N. Udagawa, N. Takahashi, K. Tanaka, Y. Oiso, Y. Seino, Gastric inhibitory polypeptide as an endogenous factor promoting new bone formation after food ingestion, Mol. Endocrinol. 20 (7) (2006) 1644-1651.

[25] K. Suzuki, N. Harada, S. Yamane, Y. Nakamura, K. Sasaki, D. Nasteska, E. Joo, K. Shibue, T. Harada, A. Hamasaki, K. Toyoda, K. Nagashima, N. Inagaki, Transcriptional regulatory factor X6 (Rfx6) increases gastric inhibitory polypeptide (GIP) expression in enteroendocrine K-cells and is involved in GIP hypersecretion in high fat diet-induced obesity, J. Biol. Chem. 288 (3) (2013) 1929-1938.

[26] D. Nasteska, N. Harada, K. Suzuki, S. Yamane, A. Hamasaki, E. Joo, K. Iwasaki, K. Shibue, T. Harada, N. Inagaki, Chronic reduction of GIP secretion alleviates obesity and insulin resistance under high-fat diet conditions, Diabetes 63 (7) (2014) 2332-2343.

[27] D. Xie, H. Cheng, M. Hamrick, Q. Zhong, K.H. Ding, D. Correa, S. Williams, A. Mulloy, W. Bollag, R.J. Bollag, R.R. Runner, J.C. McPherson, K. Insogna, C.M. Isales, Glucose-dependent insulinotropic polypeptide receptor knockout mice have altered bone turnover, Bone 37 (6) (2005) 759-769.

[28] C. Gaudin-Audrain, N. Irwin, S. Mansur, P.R. Flatt, B. Thorens, M. Basle, D. Chappard, G. Mabilleau, Glucose-dependent insulinotropic polypeptide receptor deficiency leads to modifications of trabecular bone volume and quality in mice, Bone 53 (1) (2013) 221-230.

[29] A. Mieczkowska, N. Irwin, P.R. Flatt, D. Chappard, G. Mabilleau, Glucose-dependent insulinotropic polypeptide (GIP) receptor deletion leads to reduced bone strength and quality, Bone 56 (2) (2013) 337-342.

[30] D. Flamez, A. Van Breusegem, L.A. Scrocchi, E. Quartier, D. Pipeleers, D.J. Drucker, F. Schuit, Mouse pancreatic beta-cells exhibit preserved glucose competence after disruption of the glucagon-like peptide-1 receptor gene, Diabetes 47 (4) (1998) 646-652.

[31] N. Pamir, F.C. Lynn, A.M. Buchan, J. Ehses, S.A. Hinke, J.A. Pospisilik, K. Miyawaki, Y. Yamada, Y. Seino, C.H. McIntosh, R.A. Pederson, Glucose-dependen insulinotropic polypeptide receptor null mice exhibit compensatory changes in the enteroinsular axis, Am. J. Physiol. Endocrinol. Metab. 284 (5) (2003) E931-9. 
[32] R.A. Pederson, M. Satkunarajah, C.H. McIntosh, L.A. Scrocchi, D. Flamez, F. Schuit, D.J. Drucker, M.B. Wheeler, Enhanced glucose-dependent insulinotropic polypeptide secretion and insulinotropic action in glucagon-like peptide 1 receptor -/- mice, Diabetes 47 (7) (1998) 1046-1052.

[33] A. Mieczkowska, S. Mansur, B. Bouvard, P.R. Flatt, B. Thorens, N. Irwin, D. Chappard, G. Mabilleau, Double incretin receptor knock-out (DIRKO) mice present with alterations of trabecular and cortical micromorphology and bone strength, Osteoporos. Int. 26 (1) (2015) 209-218.

[34] E.E. Mulvihill, E.M. Varin, B. Gladanac, J.E. Campbell, J.R. Ussher, L.L. Baggio, B. Yusta, J. Ayala, M.A. Burmeister, D. Matthews, K.W.A. Bang, J.E. Ayala, D.J. Drucker, Cellular sites and mechanisms linking reduction of dipeptidyl peptidase-4 activity to control of incretin hormone action and glucose homeostasis, Cell Metab. 25 (1) (2017) 152-165.

[35] N. Irwin, P.R. Flatt, Therapeutic potential for GIP receptor agonists and antagonists, Best Pract. Res. Clin. Endocrinol. Metab. 23 (4) (2009) 499-512.

[36] G. Mabilleau, A. Mieczkowska, N. Irwin, Y. Simon, M. Audran, P.R. Flatt, D. Chappard, Beneficial effects of a N-terminally modified GIP agonist on tissue-level bone material properties, Bone 63 (2014) 61-68.

[37] S.A. Mansur, A. Mieczkowska, B. Bouvard, P.R. Flatt, D. Chappard, N. Irwin, G. Mabilleau, Stable incretin mimetics counter rapid deterioration of bone quality in type 1 diabetes mellitus, J. Cell. Physiol. 230 (12) (2015) 3009-3018.

[38] D.B. Henriksen, P. Alexandersen, N.H. Bjarnason, T. Vilsboll, B. Hartmann, E.E. Henriksen, I. Byrjalsen, T. Krarup, J.J. Holst, C. Christiansen, Role of gastrointestinal hormones in postprandial reduction of bone resorption, J. Bone Miner. Res. 18 (12) (2003) 2180-2189.

[39] A. Nissen, M. Christensen, F.K. Knop, T. Vilsboll, J.J. Holst, B. Hartmann, Glucose-dependent insulinotropic polypeptide inhibits bone resorption in humans, $\mathrm{J}$. Clin. Endocrinol. Metab. 99 (11) (2014) E2325-9.

[40] S.S. Torekov, T. Harslof, L. Rejnmark, P. Eiken, J.B. Jensen, A.P. Herman, T. Hansen, O. Pedersen, J.J. Holst, B.L. Langdahl, A functional amino acid substitution in the glucose-dependent insulinotropic polypeptide receptor (GIPR) gene is associated with lower bone mineral density and increased fracture risk, J. Clin. Endocrinol. Metab. 99 (4) (2014) E729-33.

[41] J.P. Fortin, J.C. Schroeder, Y. Zhu, M. Beinborn, A.S. Kopin, Pharmacological characterization of human incretin receptor missense variants, J. Pharmacol. Exp. Ther. 332 (1) (2010) 274-280.

[42] C. Orskov, L. Rabenhoj, A. Wettergren, H. Kofod, J.J. Holst, Tissue and plasma con centrations of amidated and glycine-extended glucagon-like peptide I in humans, Diabetes 43 (4) (1994) 535-539.

[43] L.L. Baggio, D.J. Drucker, Biology of incretins: GLP-1 and GIP, Gastroenterology 132 (6) (2007) 2131-2157.

[44] J.J. Holst, C.F. Deacon, Glucagon-like peptide-1 mediates the therapeutic actions of DPP-IV inhibitors, Diabetologia 48 (4) (2005) 612-615.

[45] J.Y. Kim, S.K. Lee, K.J. Jo, D.Y. Song, D.M. Lim, K.Y. Park, L.F. Bonewald, B.J. Kim, Exendin- 4 increases bone mineral density in type 2 diabetic OLETF rats potentially through the down-regulation of SOST/sclerostin in osteocytes, Life Sci. 92 (10) (2013) 533-540.

[46] M. Pereira, J. Jeyabalan, C.S. Jorgensen, M. Hopkinson, A. Al-Jazzar, J.P. Roux, P. Chavassieux, I.R. Orriss, M.E. Cleasby, C. Chenu, Chronic administration of Glucagon-like peptide-1 receptor agonists improves trabecular bone mass and architecture in ovariectomised mice, Bone 81 (2015) 459-467.

[47] B. Nuche-Berenguer, S. Portal-Nunez, P. Moreno, N. Gonzalez, A. Acitores, A. Lopez-Herradon, P. Esbrit, I. Valverde, M.L. Villanueva-Penacarrillo, Presence of a functional receptor for GLP-1 in osteoblastic cells, independent of the cAMP-linked GLP-1 receptor, J. Cell. Physiol. 225 (2) (2010) 585-592.

[48] M.A. Luque, N. Gonzalez, L. Marquez, A. Acitores, A. Redondo, M. Morales, I. Valverde, M.L. Villanueva-Penacarrillo, Glucagon-like peptide-1 (GLP-1) and glucose metabolism in human myocytes, J. Endocrinol. 173 (3) (2002) 465-473.

[49] M.L. Villanueva-Penacarrillo, E. Delgado, M.A. Trapote, A. Alcantara, F. Clemente, M.A. Luque, A. Perea, I. Valverde, Glucagon-like peptide-1 binding to rat hepatic membranes, J. Endocrinol. 146 (1) (1995) 183-189.

[50] C. Weston, J. Lu, N. Li, K. Barkan, G.O. Richards, D.J. Roberts, T.M. Skerry, D. Poyner, M. Pardamwar, C.A. Reynolds, S.J. Dowell, G.B. Willars, G. Ladds, Modulation of glucagon receptor pharmacology by receptor activity-modifying protein-2 (RAMP2), J. Biol. Chem. 290 (38) (2015) 23009-23022.

[51] G. Mabilleau, A. Mieczkowska, N. Irwin, P.R. Flatt, D. Chappard, Optimal bone mechanical and material properties require a functional glucagon-like peptide- 1 receptor, J. Endocrinol. 219 (1) (2013) 59-68.

[52] C. Yamada, Y. Yamada, K. Tsukiyama, K. Yamada, N. Udagawa, N. Takahashi, K. Tanaka, D.J. Drucker, Y. Seino, N. Inagaki, The murine glucagon-like peptide-1 receptor is essential for control of bone resorption, Endocrinology 149 (2) (2008) 574-579.

[53] L.W. Madsen, J.A. Knauf, C. Gotfredsen, A. Pilling, I. Sjogren, S. Andersen, L. An dersen, A.S. de Boer, K. Manova, A. Barlas, S. Vundavalli, N.C. Nyborg, L.B. Knudsen, A.M. Moelck, J.A. Fagin, GLP-1 receptor agonists and the thyroid: C-cell effect in mice are mediated via the GLP-1 receptor and not associated with RET activation, Endocrinology 153 (3) (2012) 1538-1547.

[54] G. Mabilleau, M. Pereira, C. Chenu, Novel skeletal effects of glucagon-like peptide-1 (GLP-1) receptor agonists, J. Endocrinol. (2017).

[55] C. Sanz, P. Vazquez, C. Blazquez, P.A. Barrio, M. Alvarez Mdel, E. Blazquez, Signaling and biological effects of glucagon-like peptide 1 on the differentiation of mesenchymal stem cells from human bone marrow, Am. J. Physiol. Endocrinol. Metab. 298 (3) (2010) E634-43.

[56] J. He, C. Wang, Y. Sun, B. Lu, J. Cui, N. Dong, M. Zhang, Y. Liu, B. Yu, Exendin-4 protects bone marrow-derived mesenchymal stem cells against oxygen/glucose and serum deprivation-induced apoptosis through the activation of the cAMP/PKA signaling pathway and the attenuation of ER stress, Int. J. Mol. Med. 37 (4) (2016) 889-900.
[57] Y. Feng, L. Su, X. Zhong, W. Guohong, H. Xiao, Y. Li, L. Xiu, Exendin-4 promotes proliferation and differentiation of MC3T3-E1 osteoblasts by MAPKs activation, J. Mol. Endocrinol. 56 (3) (2016) 189-199.

[58] X.K. Hu, X.H. Yin, H.Q. Zhang, C.F. Guo, M.X. Tang, Liraglutide attenuates the osteoblastic differentiation of MC3T3E1 cells by modulating AMPK/mTOR signaling, Mol. Med. Rep. 14 (4) (2016) 3662-3668.

[59] J. Meng, X. Ma, N. Wang, M. Jia, L. Bi, Y. Wang, M. Li, H. Zhang, X. Xue, Z. Hou, Y. Zhou, Z. Yu, G. He, X. Luo, Activation of GLP-1 receptor promotes bone marrow stromal cell osteogenic differentiation through beta-catenin, Stem Cell Rep. 6 (4) (2016) 579-591.

[60] E.L. Pacheco-Pantoja, J.P. Dillon, P.J. Wilson, W.D. Fraser, J.A. Gallagher, c-Fos induction by gut hormones and extracellular ATP in osteoblastic-like cell lines, Purinergic Signal. 12 (4) (2016) 647-651.

[61] X. Wu, S. Li, P. Xue, Y. Li, Liraglutide, a glucagon-like peptide-1 receptor agonist, facilitates osteogenic proliferation and differentiation in MC3T3-E1 cells through phosphoinositide 3-kinase (PI3 K)/protein kinase B (AKT), extracellular signal-related kinase (ERK)1/2, and cAMP/protein kinase A (PKA) signaling pathways involving beta-catenin, Exp. Cell Res. (2017).

[62] B. Nuche-Berenguer, P. Moreno, P. Esbrit, S. Dapia, J.R. Caeiro, J. Cancelas, J.J. Haro-Mora, M.L. Villanueva-Penacarrillo, Effect of GLP-1 treatment on bone turnover in normal, type 2 diabetic, and insulin-resistant states, Calcif. Tissue Int. 84 (6) (2009) 453-461.

[63] B. Nuche-Berenguer, P. Moreno, S. Portal-Nunez, S. Dapia, P. Esbrit, M.L. Villanueva-Penacarrillo, Exendin-4 exerts osteogenic actions in insulin-resistant and type 2 diabetic states, Regul. Pept. 159 (1-3) (2010) 61-66.

[64] H.X. Sun, N. Lu, X. Luo, L. Zhao, J.M. Liu, Liraglutide, the glucagon-like peptide-1 receptor agonist, has anabolic bone effects in diabetic Goto-Kakizaki rats, J. Diabetes 7 (4) (2015) 584-588.

[65] M. Nauck, A. Frid, K. Hermansen, A.B. Thomsen, M. During, N. Shah, T. Tankova, I. Mitha, D.R. Matthews, Long-term efficacy and safety comparison of liraglutide, glimepiride and placebo, all in combination with metformin in type 2 diabetes: 2-year results from the LEAD-2 study, Diabetes Obes. Metab. 15 (3) (2013) 204-212.

[66] R. Pratley, M. Nauck, T. Bailey, E. Montanya, R. Cuddihy, S. Filetti, A. Garber, A.B. Thomsen, H. Hartvig, M. Davies, L.-D.-S. Group, One year of liraglutide treatment offers sustained and more effective glycaemic control and weight reduction compared with sitagliptin, both in combination with metformin, in patients with type 2 diabetes: a randomised, parallel-group, open-label trial, Int. J. Clin. Pract. 65 (4) (2011) 397-407.

[67] G. Mabilleau, D. Chappard, P.R. Flatt, N. Irwin, Effects of anti-diabetic drugs on bone metabolism, Expert Rev. Endocrinol. Metab. 10 (6) (2015) 663-675.

[68] X. Ma, J. Meng, M. Jia, L. Bi, Y. Zhou, Y. Wang, J. Hu, G. He, X. Luo, Exendin-4, a glucagon-like peptide- 1 receptor agonist, prevents osteopenia by promoting bone formation and suppressing bone resorption in aged ovariectomized rats, J. Bone Miner. Res. 28 (7) (2013) 1641-1652.

[69] N. Lu, H. Sun, J. Yu, X. Wang, D. Liu, L. Zhao, L. Sun, H. Zhao, B. Tao, J. Liu, Glucagon-like peptide-1 receptor agonist Liraglutide has anabolic bone effects in ovariectomized rats without diabetes, PLoS One 10 (7) (2015) e0132744.

[70] A. Mizokami, Y. Yasutake, J. Gao, M. Matsuda, I. Takahashi, H. Takeuchi, M. Hirata, Osteocalcin induces release of glucagon-like peptide-1 and thereby stimulates insulin secretion in mice, PLoS One 8 (2) (2013) e57375.

[71] A. Mizokami, Y. Yasutake, S. Higashi, T. Kawakubo-Yasukochi, S. Chishaki, I. Takahashi, H. Takeuchi, M. Hirata, Oral administration of osteocalcin improves glucose utilization by stimulating glucagon-like peptide-1 secretion, Bone 69C (2014) 68-79.

[72] G. Mabilleau, A. Mieczkowska, D. Chappard, Use of glucagon-like peptide-1 receptor agonists and bone fractures: a meta-analysis of randomized clinical trials, J. Diabetes 6 (3) (2014) 260-266.

[73] B. Su, H. Sheng, M. Zhang, L. Bu, P. Yang, L. Li, F. Li, C. Sheng, Y. Han, S. Qu, J. Wang, Risk of bone fractures associated with glucagon-like peptide-1 receptor agonists' treatment: a meta-analysis of randomized controlled trials, Endocrine 48 (1) (2015) 107-115.

[74] J.H. Driessen, R.M. Henry, H.A. van Onzenoort, A. Lalmohamed, A.M. Burden, D. Prieto-Alhambra, C. Neef, H.G. Leufkens, F. de Vries, Bone fracture risk is not associated with the use of glucagon-like peptide-1 receptor agonists: a population-based cohort analysis, Calcif. Tissue Int. 97 (2) (2015) 104-112

[75] J.H. Driessen, H.A. van Onzenoort, J. Starup-Linde, R. Henry, A.M. Burden, C. Neef J.P. van den Bergh, P. Vestergaard, F. de Vries, Use of glucagon-like-peptide 1 receptor agonists and risk of fracture as compared to use of other anti-hyperglycemic drugs, Calcif. Tissue Int. 97 (5) (2015) 506-515.

[76] S.A. Paschou, A.D. Dede, P.G. Anagnostis, A. Vryonidou, D. Morganstein, D.G Goulis, Type 2 diabetes and osteoporosis: a guide to optimal management, J. Clin. Endocrinol. Metab. 102 (10) (2017) 3621-3634.

[77] V.K. Bhat, B.D. Kerr, P.R. Flatt, V.A. Gault, A novel GIP-oxyntomodulin hybrid peptide acting through GIP, glucagon and GLP-1 receptors exhibits weight reducing and anti-diabetic properties, Biochem. Pharmacol. 85 (11) (2013) 1655-1662.

[78] V.K. Bhat, B.D. Kerr, S. Vasu, P.R. Flatt, V.A. Gault, A DPP-IV-resistant triple-acting agonist of GIP, GLP-1 and glucagon receptors with potent glucose-lowering and insulinotropic actions in high-fat-fed mice, Diabetologia 56 (6) (2013) 1417-1424.

[79] J.W. Day, N. Ottaway, J.T. Patterson, V. Gelfanov, D. Smiley, J. Gidda, H. Findeisen, D. Bruemmer, D.J. Drucker, N. Chaudhary, J. Holland, J. Hembree, W. Abplanalp, E. Grant, J. Ruehl, H. Wilson, H. Kirchner, S.H. Lockie, S. Hofmann, S.C. Woods, R. Nogueiras, P.T. Pfluger, D. Perez-Tilve, R. DiMarchi, M.H. Tschop, A new glucagon and GLP-1 co-agonist eliminates obesity in rodents, Nat. Chem. Biol. 5 (10) (2009) 749-757.

[80] B. Finan, T. Ma, N. Ottaway, T.D. Muller, K.M. Habegger, K.M. Heppner, H. Kirchner, J. Holland, J. Hembree, C. Raver, S.H. Lockie, D.L. Smiley, V. Gelfanov, B. Yang, S. Hofmann, D. Bruemmer, D.J. Drucker, P.T. Pfluger, D. Perez-Tilve, J. Gidda, L. Vignati, L. Zhang, J.B. Hauptman, M. Lau, M. Brecheisen, S. Uhles, W. Ri- 
Tschop, Unimolecular dual incretins maximize metabolic benefits in rodents, monkeys, and humans, Sci. Transl. Med. 5 (209) (2013) 209 ra151.

[81] B. Finan, B. Yang, N. Ottaway, D.L. Smiley, T. Ma, C. Clemmensen, J. Chabenne, L. Zhang, K.M. Habegger, K. Fischer, J.E. Campbell, D. Sandoval, R.J. Seeley, K. Bleicher, S. Uhles, W. Riboulet, J. Funk, C. Hertel, S. Belli, E. Sebokova, K. Conde-Knape, A. Konkar, D.J. Drucker, V. Gelfanov, P.T. Pfluger, T.D. Muller, D. Perez-Tilve, R.D. DiMarchi, M.H. Tschop, A rationally designed monomeric peptide triagonist corrects obesity and diabetes in rodents, Nat. Med. 21 (1) (2015) 27-36.

[82] K. Fosgerau, L. Jessen, J. Lind Tolborg, T. Osterlund, K. Schaeffer Larsen, K. Rolsted, M. Brorson, J. Jelsing, T. Skovlund Ryge Neerup, The novel GLP-1-gastrin dual agonist, ZP3022, increases beta-cell mass and prevents diabetes in $\mathrm{db} / \mathrm{db}$ mice, Diabetes Obes. Metab. 15 (1) (2013) 62-71.

[83] V.A. Gault, V.K. Bhat, N. Irwin, P.R. Flatt, A novel glucagon-like peptide-1 (GLP-1)/ glucagon hybrid peptide with triple-acting agonist activity at glucose-dependent insulinotropic polypeptide, GLP-1, and glucagon receptors and therapeutic potential in high fat-fed mice, J. Biol. Chem. 288 (49) (2013) 35581-35591.

[84] A. Hasib, M.T. Ng, V.A. Gault, D. Khan, V. Parthsarathy, P.R. Flatt, N. Irwin, An en zymatically stable GIP/xenin hybrid peptide restores GIP sensitivity, enhances beta cell function and improves glucose homeostasis in high-fat-fed mice, Diabetologia 60 (3) (2017) 541-552.

[85] N. Irwin, V. Pathak, P.R. Flatt, A novel CCK-8/GLP-1 hybrid peptide exhibiting prominent insulinotropic, glucose-lowering, and satiety actions with significant therapeutic potential in high-fat-fed mice, Diabetes 64 (8) (2015) 2996-3009.
[86] A. Pocai, P.E. Carrington, J.R. Adams, M. Wright, G. Eiermann, L. Zhu, X. Du, A. Petrov, M.E. Lassman, G. Jiang, F. Liu, C. Miller, L.M. Tota, G. Zhou, X. Zhang, M.M. Sountis, A. Santoprete, E. Capito, G.G. Chicchi, N. Thornberry, E. Bianchi, A. Pessi, D.J. Marsh, R. SinhaRoy, Glucagon-like peptide 1/glucagon receptor dual agonism reverses obesity in mice, Diabetes 58 (10) (2009) 2258-2266.

[87] L.B. Jensen, F. Quaade, O.H. Sorensen, Bone loss accompanying voluntary weight loss in obese humans, J. Bone Miner. Res. 9 (4) (1994) 459-463.

[88] J.A. Langlois, M.E. Mussolino, M. Visser, A.C. Looker, T. Harris, J. Madans, Weight loss from maximum body weight among middle-aged and older white women and the risk of hip fracture: the NHANES I epidemiologic follow-up study, Osteoporos. Int. 12 (9) (2001) 763-768.

[89] J.P. Frias, E.J. Bastyr 3rd, L. Vignati, M.H. Tschop, C. Schmitt, K. Owen, R.H. Christensen, R.D. DiMarchi, The sustained effects of a dual GIP/GLP-1 receptor agonist, NNC0090-2746, in patients with type 2 diabetes, Cell Metab. 26 (2) (2017) 343-352e2.

[90] S.A. Mansur, A. Mieczkowska, P.R. Flatt, B. Bouvard, D. Chappard, N. Irwin, G. Mabilleau, A new stable GIP-Oxyntomodulin hybrid peptide improved bone strength both at the organ and tissue levels in genetically-inherited type 2 diabetes mellitus, Bone 87 (2016) 102-113. 